\title{
Edward Paulino
}

Dividing Hispaniola: The Dominican Republic's Border Campaign against Haiti, 1930-1961. Pittsburgh: University of Pittsburgh Press, 2016. xiv + 267 pp. (Paper US\$27.95)

Dividing Hispaniola revisits the bloody ground of Hispaniola's border region, and joins in the debate about the origins of Dominican acrimony toward Haiti, with a focus on the "Haitian Massacre" of 1937. Edward Paulino's exertive research is the book's greatest contribution to that lengthy historiography.

In this account, Paulino brings to light new information from the Archivo General de la Nación (AGN), becoming one of the first scholars to benefit from the extreme makeover that the repository has recently experienced. Gone are the days of giant piles of folios of documents on the floor and holes in the roof! Today's AGN is an accessible facility that allowed him to mine the records of the Army and the Department of Agriculture, among other sources. Outside the AGN, he traveled extensively in the border region, conducting scores of sickeningly gory interviews with elderly informants who detailed the slaughter of 1937. Moreover, he gained access to the storied Secret Archive of The Vatican, which contains documents showing that the pope's personal emissary to Hispaniola brokered the deal that defused the postmassacre war scare between the Dominican Republic and Haiti. These feats of scholarly sleuthing deserve the attention of everyone interested in the tangled history of those nations, as well as anyone who would like to learn more about genocide. (Please, let us stop using the verbal dodge "ethnic cleansing.")

The prologue relates Paulino's personal experience to his subject. It is a moving essay unto itself, capturing the conflicted duality of Dominican American identity. Americans of Dominican ethnicity live behind their own kind of veil, to borrow the metaphor of W.E.B. DuBois, which Paulino expresses eloquently here.

Dividing Hispaniola mainly repeats the case made by Lauren H. Derby and Richard Turits, in their respective bodies of work, that the border region was a harmonious transnational space until the Trujillo regime's attempt to divide the nations. This project of separating the inseparable, the argument goes, required both a literal effort, which inflicted extreme violence against individuals of Haitian ethnicity, and a figurative one, which inflicted extreme violence against the historical record. Despite that, "both nations are inextricably linked, two wings of one bird" (p. 12).

The book's chapter titles speak volumes, and merit full citation. The first, "'The Barbarians Who Threaten This Part of the World': Protecting the Unenforceable," summarizes the history of the island's East vs. West conflict, dis-

(C) ERIC PAUL ROORDA, 2018 | DOI: $10.1163 / 22134360-09201021$

This is an open access article distributed under the terms of the prevailing CC-BY-NC license 
puting that the so-called Haitian Occupation and subsequent invasions of the Dominican Republic by expansionist Haitian autocrats left a legacy of bitterness. In this account, racist marines were responsible for setting the stage for the Haitian Massacre. "'Making Crosses on His Chest': U.S. Occupation Confronts a Border Insurgency" makes extensive use of the Senate hearings conducted in 1920-21, extracting some of the grisliest details from them. The heart of the book, a chapter entitled “'A Systematic Campaign of Extermination': Racial Agenda on the Border," recounts the mass murders of 1937, often in the words of the aged witnesses and participants Paulino interviewed. The diplomatic aftermath of the event is much less of a riddle as a result of this chapter's Vatican Secret Archive revelations. Paulino's many hours at the AGN allowed him to write "'Demands of Civilization': Changing Identity by Remapping and Renaming," which draws from the Army and Agriculture files. Readers should pay close attention to the footnotes, where many rich details can be found.

Further evidence for state-imposed racism comes in the chapter "Silent Invasions': Anti-Haitian Propaganda," which might be entitled with a paraphrase from Herman Melville: "The Metaphysics of Haitian-Hating and NationBuilding." In it, Paulino reveals that certain prominent Dominicans worked as "border agents," reporting covertly on Haitian activities. These included two noted novelists-Ramón Marrero Aristy, author of the sugar industry exposé Over (1939), and Freddy Prestol Castor, who wrote El Masacre se pasa a pie (1973), a thinly fictionalized account of the Haitian Massacre. Paulino goes on to analyze the venomous verbiage of a cadre of intellectuals he dubs Los Guaraguaos, or Warhawks, led by the relatively obscure Manuel Arturo Peña Batlle and the more famous future president of the republic, Joaquín Balaguer. Their rantings are juxtaposed here with the lucid critique of Dominican-style racism that Jean Price-Mars set forth (in three volumes!) in 1942. Further, the chapter relates how education and even music became tools of "dominicanization."

The brief concluding chapter, "Instructed to Register as White or Mulatto': White Numerical Ascendancy," reconstructs the demographic identities that the complexion-obsessed Trujillo regime imposed on its population, converting lighter brown skin to white and darker brown to "Indio." Paulino's epilogue gets to his personal point, which is that anti-Haitian racism on a massive scale in the Dominican Republic was carefully constructed by a hateful regime, and now needs to be repudiated and dismantled.

\section{Eric Paul Roorda}

Department of History, Bellarmine University

eroorda@bellarmine.edu 